\title{
Determinants of Instructional Leadership Practice at Colleges of Teacher Education in Amhara Region, Ethiopia
}

\author{
Molalign Tamru, PhD \\ Assistant Professor \\ Debre Markos University, Ethiopia
}

\author{
Atalay Mefin \\ MA \\ Lecturer at Debre Markos College of Teacher \\ Education, Ethiopia
}

\begin{abstract}
This study was mainly aimed at to assess the hampering factors of instructional leadership execution at colleges of teacher education in Amhararegion, Ethiopia. from the perspective of Hallinger and Murphy (1985) functions. To this end, the research firstly tried it attempted to explore whether there were statistically significant mean difference among instructional leadership function execution and colleges of teacher education in execution and it also tried to see the predictive value of independent variable (lack o vision, lack of time, lack of skill and training, lack of resource and lack of cooperation) on the dependent variable (effectiveness of instructional leadership function execution). The researchers have used a descriptive survey research design with purely quantitative approach. The data collected through different instruments from 196 teachers and $3513^{\text {rd }}$ year regular students were analyzed by considering the nature of data collected. the quantitative data analysis techniques ( regression, correlation, post hock and ANOVA) were used to analyze the data collected through closed-ended items of the questionnaires. From the analyses of the data collected, the major findings were standout in the study. The identified hindrance factors predict the effectiveness of instructional leadership function execution by $(\mathrm{r}=0.646) 64.6 \%$ and lack of resource was found out the major hindrance factor $(r=0.42)$ and statistically significant mean difference were found between four colleges of teacher education in instructional leadership function execution $(\mathrm{P}<0.01)$ and there were also statistically significance mean difference among ten instructional leadership function execution $(\mathrm{P}<0.01)$. Finally, the researchers has drawn major conclusion under each research question. Based on this, recommendations were forwarded to different stakeholders like MoE, REB, college deans, teachers and students.
\end{abstract}

\section{Keywords}

Instructional leadership, hindrance factors, execute and opportunities

\section{INTRODUCTION}

Education, as explained by different scholars, its importance is accepted all over the world for its ability to develop human potential and contribution to economic growth. Because welleducated citizens contribute more for one's country economy and social development (Foskett\&Lumby, 2003). In this regard, Aikaman\&Unterhalter (2005) also stated that as economies become more dependent on high-technology industries and on the service sector, the desire for welleducated and highly trained workforce becomes imperative and mandatory. Since the current educational leaders capacity of decision-making organs of the education system in Ethiopia widely coupled with different limitations; the instructional leadership development programs in Ethiopia require a serious attention of the policy makers (Maeregu, Ashebir,Gizachew, Ferew\&Alem, 2016).On the other hand, the previous training programs for educational leadership have been criticized for equipping leaders with the skills to run education organization as they existcomplex today. Thus, a need to develop the instructional leadership program becomes urgent to solve different educational problems through using effective leadership function (Hallinger,2003) .

The issue of effective instructional leadership function execution is highly related with accomplishing mission, vision, protecting instructional time from interruption, promoting professional development and incentive for learning and for teachers (Hallinger\& Murphy, 1985). The effective implementation of those activities made an educational organization become fruitful enough. Sound performance of effective instructional leadership function execution is one of the most important contributors to the overall education performances and success in any country (Bush, 2008). Other researchers like Fullan, Miles \&Taylor (2003)cited in Castro Zulu (2004) stated that, without the effective instructional leadership, educational organization could suffer from different challenges.

Effective instructional leaders were viewed as culture builders in a given organization and they sought to create an academic press that fostered high expectations and standards for students and aswell as for teachers (Hallinger\& Murphy, 1985). In addition, effective instructional leaders can understand people, focus on the improvement of students' achievement, create and communicate clear vision, mission, goal and plan towards the education reform. Some of the challenges identified by the former researcher qualitatively were the following.

Lack of Skills and Training: As Sergiovanni (2001) stated that, technical, human and educational skills, abilities and knowledge are essential properties that instructional leaders have to possess. Instructional leaders without adequate skills and training in educational leadership and professional development of teachers can do little or no for the improvement of learning (West-Burnham, 1998).

B. Lack of Cooperation from Superiors and Teachers: Teacherse cooperation is essential for effective instructional leadership. The cooperation of teachers, students, and parents could be available in school climate where the leaders exercise democratic leadership (MoE, 2002). 
C. Lack of Time: Educational leaders have multiple roles they have to play. Some are information over load, paper work, too many reports, many non-academic demands and work over load consume much of the leaders time. Therefore only education leaders committed to instructional improvement can choose and use their time for the enhancement of the classroom instruction and teacher development (Harris \&Muijs 2003).

D. Lack of Adequate Resources: Lack of adequate resources of all type and support from central offices discourages instructional leaders. Bureaucratic management that hampers timely assignment human, financial and materials resources required can be restricted the success of the organization and limits development of the teachers (Dimmock, 2000).

E. Lack of Vision, Will and Courage: Nothing can affect instructional improvement more than lack of leaders will. Instructional leaders have to spend more time on improving the teaching learning, initiating changes and encouraging others to achieve educational goals. However lack of vision, will and courage could hinder the effectiveness of leadership performance (Sergiovanni, 2001).

Generally, the barriers of instructional leadership hinder the leader's performance, sabotage leaders' attempts and finally bring a serious problem on the quality of education. Those aren't the only factors that hinder the execution of instructional leadership but other issues like size of the organization, individual behavior and other listed as road backing factors

\section{STATEMENTS OF THE PROBLEM}

Quality of instructional leaders has become a concern across the education systems of the world. Currently, few issues like reporting, missing instructional time through meeting and organizing students in different critical mass have received more attention than the how of staffing classrooms with adequately qualified instructional leaders (Mullis, 2000). In addition to this, the effective instructional leadership reviewed by Leithwood, Jantzi, \& Steinbach (1999) in the contemporary literature that instructional leadership is one of the most frequently mentioned element in the successfulness of education organizations.

Though the issue of instructional leadership is over researched, some were limited on the following issues.study on strategic instructional leadership execution of school principals (Ghavifekr\& et al, 2014) was restricted by teachers' perceptions and highly focused on instructional leadership perceived by school teachers. Besides, locally conducted research by Maeregu\& et al (2016) on challenges of educational leadership development program was concerned on assessing the existing educational leadership development programs to identify the major challenges hinder to execute Hallinger\& Murphy (1985) instructional leadership function. Besides, the research wasn't specifically focused on instructional leadership function execution.

Moreover, Syarwan \& Maznah (2012) also conducted a research which aimed at instructional leadership on managing instructional time which left other nine instructional leadership functions like providing incentives for teachers, providing incentives for learning, professional development, defining mission and vision and promoting positive learning environment. But the researchers did not found a research shows the predictive value of the identified challenges on the effectiveness of instructional leadership functions. Based on this reason, the following research question was posed.
1. Is there statistically significant mean difference among the ten Hallinger and Murphy (1985) instructional leadership functions execution?

2. What was the major predictor for the effectiveness of instructional leadership function execution among LR, LT, LC, LST and LV at colleges of teacher education?

\section{SIGNIFICANCE OF THE STUDY}

This study has supreme importance by investigatingthe extent of instructional leadership execution, hindrance factors and opportunities provided to practice instructional leadership. Thus,college of teacher education and regional education bureau, deans and department heads as well as students and teachers will be beneficiaries of this study. In addition, scholars from the field of study may use as a spring board for further detail studies.

\section{RESEARCH DESIGN}

To conduct this study, the researchers have used the descriptive survey design with purely quantitative approach. This is because the data were collected through questionnaires and the data were also analyzed through ANOVA and regression analysis.

\section{POPULATION OF THE STUDY}

The populations of this study were teachers (400) and students (3762). The researchersfocushis total population on 3rd year regular students for different reasons. Some of the reasons that were made the researcher to focus on 3rd year regular students were: first the students have knowledge about instructional leadership because they have learnt it at EDPM-302(School management and school improvement). Second 3rd year regular students got a chance to teach independently in different schools this made the researchers assumed that they know a lot about elements of instructional leadership and respond against each question raised to evaluate the hampering factors on the execution of instructional leadership function.

\section{SAMPLING TECHNIQUES}

Based on college of Teacher education proclamation of inauguration (proclamation 2004and 2009) colleges of teacher education in Amhara region were categorized in to two which are new and old generation. Based on this, the sampling technique employed was stratified simple random sampling technique.

\section{DATA GATHERING INSTRUMENTS}

A questionnaire is a paper and pencil instrument that asks the same questions of all members of the sample unite, and which respondents can answer at their own convenience (Gall and Borg, 2007). Based on the above description, the researcher chosen questionnaire because it is a quick way of gathering data and it can reach a largenumber of subjects and it is widely used in most educational researches.

\section{RELIABILITY AND VALIDITY OF THE INSTRUMENTS}

Reliability of the Instruments: After collecting data from the objective groups of 3rd year students from FenoteSelam College of Teacher education, the collected data was interred in to Statistical Package for Social science (SPSS-Version-20) to make it ready for reliability test. Next, the reliability statistics was calculated by using cronbach's alpha and the obtained reliability statistics of adapted instrument instruments were 0.93 for students ' questioner. The teachers' questionnaires reliability statistics were also checked using 30 
teachers and the obtained reliability statistics were 0.91 for adapted instrument. The adapted instruments were pilot tested to check in the case ofteachers' context at colleges of teacher education. In addition the self-developed questionnaires were checked and its reliability statistics were become 8.31.

Validity of the Instruments: Checking thevalidity of the data collecting instruments is the most important procedure that a data collection instrument can possess. Based on this, the researcher tried to check the validity of the instruments by inviting different professional (experts) from department of education and department of language. The content validity (if it can measure an intended content area for the study), construct validity (what the instrument is really measure?) were checked to make the instrument valid.

\section{QUANTITATIVE DATA ANALYSIS TECHNIQUE}

Quantitative data analysis technique was employed to analyze data collected through questionnaire. After the raw data collected, it was grouped, organized and analyzed with quantitative data analyses techniques. From the quantitative data analysis technique ANOVA followed by Post hock, Percentage, frequency, Mean, standard deviation, Correlation (to calculate multicoliniarity of independent variables) and Stepwise Multiple Linear regression were used. Some of the details of quantitative data collection instrument are presented under here.

ANOVA: One way analysis of variance was used to analyze the data collected to answer the presence/absence of statistical mean difference among colleges of teacher education in execution of instructional leadership function and also among ten instructional leadership functions.

Correlation: Before the researcher was going to analyze the predictive value of the independent variable on the dependent variable, the assumption of linear multiple regression should be checked. Based on this, one of the assumptions was that the absence of strong correlation between independent variable. Based on this, the researcher have used correlation to check the multicolliniarity assumption

Stepwise Multiple Linear Regressions: This quantitative (inferential statistics) data analysis technique was used to calculate the cumulative effect of the independent variable on the dependent variable. Stepwise multiple regressions is used to calculate the prediction power of variables starting from the variable w410hich has high predictive value (having high correlation with the criterion variable but not the independent variable) up to the variable having list predictive value. In addition, stepwise regression was used to identify the most significant predictor variables and their relative contribution in the explained variable.

\section{VARIABLES OF THE STUDY}

Dependent Variable of the Study: The dependent variable for this study effectiveness of instructional leadership function execution.

Independent Variables of the Study: The study has five independent variables which determine the dependent variable. The independent variables were lack of time, lack of will and courage, lack of skill and training, lack of vision and lack of resource. The independent variable which hampered the effectiveness of instructional leadership execution was identified by different former scholars (Sergiovanni, 2001; MoE, 2002; Harris and Muijs, 2003 \& Dimmock, 2000).

\section{DATA ANALYSIS AND INTERPRETATION OF RESULTS Checking Assumption to Use Inferential Statistics}

Table 4.1 Normality Test to check the normal distribution

\begin{tabular}{|l|l|l|}
\hline Key functions & \multicolumn{2}{|l|}{ Kolmogorov-Smirnov } \\
\cline { 2 - 3 } & Statistic & Sig. \\
\hline Framing the College Goals & 0.980 & .000 \\
\hline Communicating College Goals & 0.923 & .000 \\
\hline Supervision and Evaluating Instructions & 0.942 & .000 \\
\hline Coordinating the Curriculum & 0.960 & .000 \\
\hline Monitoring Students' Progress & 0.916 & .000 \\
\hline Protecting Instructional Time & 0.938 & .000 \\
\hline Promoting Professional Development & 0.918 & .000 \\
\hline Maintaining High Visibility & 0.949 & .000 \\
\hline Providing Incentives for Teachers & 0.921 & .000 \\
\hline Providing Incentives for Learning & 0.948 & .000 \\
\hline
\end{tabular}

The test statistics shown in table 4.1 above; two tests for normality are calculated and run. But, for the datasheet smaller than 2000 and samples with 50 responses we should have to use Shaprio-Wilk test. Otherwise, the KolmogorovSmirnov test is used. To conclude that the data came from the normal distribution the P-value should be found less than
0.05 . Another assumption about normality test value is that when the obtained statistics is found between -1.96 and 1.96 the distribution is normal. Based on this assumption, the obtained statistical value in table 4.3 told us that the distribution is normal and accepted to use regression analysis. 
Table 4.2 Multi-Colliniarity Test of Independent Variable

\begin{tabular}{|l|l|l|l|l|l|}
\hline Variables & $\mathrm{X} 1$ & $\mathrm{X} 2$ & $\mathrm{X} 3$ & $\mathrm{X} 4$ & $\mathrm{X} 5$ \\
\hline Lack of skill and training(X1) & &. & & & \\
\hline lack of vision(X2) & .01 & & & & \\
\hline lack of resource(X3) & .12 & .01 & & & \\
\hline lack of time(X4) & .05 & .07 & .01 & & \\
\hline lack of cooperation(X5) & .16 & .74 & .10 & .06 & \\
\hline Tolerance & .869 & .17 & .942 & .732 & .689 \\
\hline VIF & 1.151 & 1.365 & 1.062 & 1.366 & 1.450 \\
\hline
\end{tabular}

In a research applying multiple regression analysis, it is always expected that a predictor variable selected by the researcher might be correlated with the criterion variable, but that is not strongly correlated with any other predictor variable. The term multi-collinearity is used to describe the situation when a high correlation is detected between two or more predictor variables. Such high correlations cause problems when trying to draw inferences about the relative contribution of each predictor variable to the success of the model(Montgomery, Vining, and Peck, 2006). Field (2009) also recommend that, in a multiple regression analysis, the researcher needs to check and ensure that the assumption of multi-collinearity had not been violated by having any variable that was too closely related to another by checking the Pearson correlation coefficient (R), the tolerance level (T) and the variance inflation factor (VIF) among the predictive variables. The absence of multi-colliniarity test is prerequisite for regression analysis. After calculating the multi Collinearitytest, the researcher tried to discus with the assumption. The general rule of thumb states that when a variance inflation factor (VIF) of a given predictor variable is less than five $(\mathrm{VIF}<5)$, the level of tolerance $(\mathrm{T})$ is greater than or equal to zero point two $(\mathrm{T} \geq 0.2)$, and its correlation coefficient(r) with other predictor variable is less than zero point eight $(\mathrm{R}<0.8)$, the predictor variable has no multicollinearity problem (Green and Salkind, 2014). Hence, assessmentof multi-collinearity among the above mentioned five predictor variables is not a threat in this research. This is because; neither the tolerance, correlation coefficient(R) nor thevariance inflation factor(VIF) indicated on table 4.5 above shows a significant presence of multi-collinearity. Thus, it is possible to use different inferential analysis such as ANOVA, Regression and Post hock analysis.

Table 4.3 One Way Analysis of Variance (ANOVA) to check the Statistical mean difference among College of Teacher Education

\begin{tabular}{|c|c|c|c|c|c|c|}
\hline & & $\begin{array}{l}\text { Sum of } \\
\text { Squares }\end{array}$ & Df & $\begin{array}{l}\text { Mean } \\
\text { Square }\end{array}$ & $\mathrm{F}$ & $\begin{array}{c}\mathrm{P}- \\
\text { value. }\end{array}$ \\
\hline \multirow{3}{*}{$\begin{array}{l}\text { College of teacher education } \\
\text { ( } 4 \text { colleges })\end{array}$} & Between Groups & 158.778 & 3 & 39.694 & \multirow[t]{3}{*}{38.776} & \multirow[t]{3}{*}{.000} \\
\hline & Within Groups & 354.197 & 346 & 1.024 & & \\
\hline & Total & 512.974 & 350 & & & \\
\hline \multirow{3}{*}{$\begin{array}{l}\text { Instructional Leadership } \\
\text { Function (10 function) }\end{array}$} & Between Groups & 98.131 & 9 & 24.533 & \multirow[t]{3}{*}{25.210} & \multirow[t]{3}{*}{.000} \\
\hline & Within Groups & 336.712 & 346 & .973 & & \\
\hline & Total & 434.843 & 355 & & & \\
\hline
\end{tabular}

The one way analysis of variance displayed in Table 4.3 revealed that there was a statistically significant variation in the execution of instructional leadership among colleges of teacher education. This is because at $\mathrm{df}=3,346$ and 0.05 alpha level; the obtained value of $\mathrm{F} / 38.776$ / was found greater than its table value. In fact the above ANOVA output results assured that the statistically significant difference was obtained among colleges of teacher's education but it doesn't tell us that between which and which college statistically significance difference was observed. To know this, using a post hock analysis was found very important. The execution in different functions of instructional leadership also found statistically significant. This is also because at $\mathrm{df}=9,346$ $\mathrm{P}<0.05$ which is $\mathrm{p}=0.000$ is statistically significant. But the post hock analysis is also important here to know which instructional leadership function was executed effectively and which was not. 
Table 4.4 Post hock analysis to check the statistical mean difference among CsTE

\begin{tabular}{|l|l|l|l|l|l|l|}
\hline No & College & Mean & 1 & 2 & 3 & 4 \\
\hline 1 & DMCTE & 10.81 & - & & & \\
\hline 2 & DBCTE & 10.93 & & - & & \\
\hline 3 & WCTE & 11.06 & & & - & \\
\hline 4 & ECTE & 14.70 & $* *$ & $*$ & $*$ & - \\
\hline
\end{tabular}

**the mean difference is significant at $P<0.01 *$ the mean difference is significant at $P<0.05$

Table 4.4 above portrays that the statistically significant mean difference was observed between colleges of teacher education. The statistical difference was found between ECTE with other three colleges of teacher education namely
DMCTE, DBCTE and WCTE $(\mathrm{P}<0.01)$. The other statistically significant mean difference $(\mathrm{p}<0.05)$ was found between ECTE with DBTCE and WCTE.

Table 4.5 Post hock Analysis to Check the Statistical Mean Difference among instructional leadership execution among different function

\begin{tabular}{|c|c|c|c|c|c|c|c|c|c|c|c|c|}
\hline z & Functions & Mean & 1 & 2 & 3 & 4 & 5 & 6 & 7 & 8 & 9 & 10 \\
\hline 1 & Supervision instructions (5 items) & 8.85 & - & & & & & & & & & \\
\hline 2 & Protecting Instructional Time (5 items) & 10.95 & & - & & & & & & & & \\
\hline 3 & Communicating Goals (5 items) & 11.01 & & & - & & & & & & & \\
\hline 4 & Providing Incentives for Learning (5 items) & 12.13 & & & & - & & & & & & \\
\hline 5 & Coordinating the Curriculum (5 items) & 12.34 & & & & & - & & & & & \\
\hline 6 & Maintaining High Visibility (5 items) & 12.36 & & & & & & - & & & & \\
\hline 7 & Providing Incentives for Teachers (5 items) & 12.44 & & & & & & & - & & & \\
\hline 8 & Monitoring Students' Progress (5 items) & 12.53 & & & & & & & & - & & \\
\hline 9 & Promoting Professional development (5 items) & 12.56 & & & & & & & & & - & \\
\hline 10 & Framing Goals $\quad$ (5 items) & 12.71 & $\begin{array}{l}* \\
*\end{array}$ & $\begin{array}{l}* \\
*\end{array}$ & $*$ & - & - & - & - & - & - & - \\
\hline
\end{tabular}

**Mean difference is significant at $P<0.01$ levels and *Mean difference is significant at $P<0.05$ levels

The post hock analysis above at table 4.5 portrays that there was astatically significant difference between the executions of different instructional leadership function. There was statistically significant mean difference between framing goals with supervising instruction and protecting instructional time at $\mathrm{P}<0.01$ level. And there were also statistically significance mean difference between framing goals and communicating goals at $\mathrm{p}<0.05$ level. However, on the rest instructional leadership functions execution, there was no statistically significance mean difference between them.

Table 4.6 Multiple Linear Regression Analysis of Five Predictor(X1-X5) Variables on the effectiveness of instructional leadership functionexecution at colleges of teacher education (Y)

\begin{tabular}{|c|c|c|c|c|c|c|}
\hline \multicolumn{2}{|c|}{ Model } & \multicolumn{2}{|c|}{$\begin{array}{l}\text { Unstandardized } \\
\text { Coefficients }\end{array}$} & \multirow{3}{*}{$\begin{array}{c}\text { Standardized } \\
\text { Coefficients }\end{array}$} & \multirow{3}{*}{$\begin{array}{r}\mathrm{t}-\text { value } \\
4.299\end{array}$} & \multirow{3}{*}{$\begin{array}{r}\text { P-value. } \\
.000\end{array}$} \\
\hline & & \multirow{2}{*}{$\begin{array}{l}\text { B } \\
.889\end{array}$} & \multirow{2}{*}{$\begin{array}{l}\text { SE } \\
.207\end{array}$} & & & \\
\hline 1 & (Constant) & & & & & \\
\hline & Lack of skill and training(X1) & -.171 & .064 & -.110 & -2.677 & .008 \\
\hline & Lack of vision(X2) & -.440 & .067 & -.294 & -6.596 & .000 \\
\hline & Lack of resource $(\mathrm{X} 3)$ & .572 & .042 & .534 & 13.553 & .000 \\
\hline & Lack of time(X4) & .119 & .053 & .101 & 2.261 & .024 \\
\hline & Lack of cooperation(X5) & .567 & .055 & .477 & 10.360 & .000 \\
\hline
\end{tabular}




\section{Note: $t$-values $\geq 4.299$ significant at $p<0.01$, $\mathrm{df}=350$}

The Regression equation

$$
\mathrm{Y}(\mathrm{EILE})=.889+-.171 \mathrm{X} 1+-.440 \mathrm{X} 2+.572 \mathrm{X} 3+.119 \mathrm{X} 4+.567 \mathrm{X} 5
$$

As it was stated byLandauandEveritt(2004).Applying multiple regression analysis to a set of data results in what are known as regression coefficients, one for each explanatory variable. These coefficients give the estimated change in the response variable associated with a unit change in the corresponding explanatory variable, conditional on the other explanatory variables remaining constant.

Taking the regression equation demonstrated above into account, we can make the following statements. The first number in the regression equation is .889 ; this isthe intercept or the constant. This means that when the values of all the five selected predictor variables become zero, the value of the dependent variable (effectiveness of instructional leadership function execution) will be .889 .Similarly, the regression coefficient of $\mathrm{X} 1$ is -.171 (i.e. the slop of the line).This implies that holding other variables being constant, a unit increase in lack of skill and training (X1) decrease the value of the dependent variable (effectiveness of instructional leadership function execution) by 0.171 . We can make the same interpretation for the rest of four predictor variables by taking each regression coefficient as a slop of the regression equation.

The focus of this research is to determine the individual and combined (composite) effect of the five predictor variables. Hence, first it is important to analyze the independent contribution of each potential predictor variable, whether they are statistically significant and, if so, the direction of the relationship. For doing such analysis, the regression coefficients, and the partial t-test were used with degree of freedom $(\mathrm{df}=350)$ and level of significance $(\mathrm{p}<0.05)$.

Lack of skill and training (X1, $\beta=-.171)$ is statistically significant $(\mathrm{p}=0.008)$, and the regression coefficient is

Table 4.7One way Analysis of Variance (ANOVA) of the Regression Model

\begin{tabular}{|l|l|l|l|l|l|l|}
\hline \multicolumn{2}{|l|}{ Model } & Sum of Squares & df & $\begin{array}{l}\text { Mean } \\
\text { Square }\end{array}$ & F & Sig. \\
\hline \multirow{2}{*}{1} & Regression & 175.987 & 6 & 35.197 & 67.95 & $.000^{\mathrm{a}}$ \\
\cline { 2 - 7 } & Residual & 178.720 & 345 & .518 & & \\
\cline { 2 - 7 } & Total & 354.707 & 351 & & & \\
\hline
\end{tabular}

The SPSS output also labeled on ANOVA for analysis, look at (table 4.7 above. It provides results for a test of significance for R, R2 and adjusted R2 using the F-statistic. In this analysis, the $\mathrm{p}$-value is well below $0.05(\mathrm{p}=0.000)$ at degree of freedom $(\mathrm{df}=6,345)$ and $(\mathrm{F}=0.67 .95)$. Therefore, we can conclude that R, R2 and adjusted R2 that exist between the negative which would indicate that high level oflack of skill and training is related to lower execution of instructional leadership at colleges of teacher education. In the same way, other four predictor variables (X2,X3,X4 and $\mathrm{X} 5)$ have statistically significant relationship with the criterion variable (effectiveness of instructional leadership function execution $=\mathrm{Y})$ though their direction of relationship is not the same. When we see their level of significance $(X 2, B=-.440$, $\mathrm{p}=.000), \quad(\mathrm{X} 3 \quad \mathrm{~B}=572, \mathrm{p}=000), \quad(\mathrm{X} 4 ., \mathrm{B}=119, \mathrm{p}=024) \quad$ and $(X 5, B=567, p=000)$ Here, we can see that all the treated variable have statistically predict the criterion variable which is effectiveness of instructional leadership function execution,

The beta value is a measure of how strongly each predictor variable influences the criterion variable. The beta is measured in units of standard deviation. When we have more than one predictor variable, the beta regression coefficient is computed to allow us to make such comparisons and to assess the strength of the relationship between each predictor variable $(\mathrm{X} 1-\mathrm{X} 5)$ with the criterion variable $(\mathrm{Y})$.

From the SPSS output, the researcher found out that lack of vision (X2), lack of resource (X3) and lack of cooperation (X5) were significant predictors of the criterion variable. On the other hand, we find that lack of skill and training (X1) and lack of time(X5) has the effect on effectiveness of instructional leadership function execution next to other three predictive variables ( $\mathrm{p}=008$ and .024$)$ respectively.

\section{Regression Analysis}

A multiple regression analysis was conducted to see if lack of resource, lack of cooperation, lack of vision, lack of skill and training and lack of time could predict the effectiveness of instructional leadership function execution. As the ANOVA summary in Table 4.10 indicates, the model is fit to predict effectiveness of instructional leadership function execution from lack of resource, lack of cooperation, lack of vision, lack of skill and training and lack of time as it was found statistically significant $([6,345 ; \mathrm{F}=67.95, \mathrm{p}<0.01])$

\section{Table 4.8Model Summary of Regression}

\begin{tabular}{|l|l|l|l|l|}
\hline Model & $\mathrm{R}$ & R Square & Adjusted R Square & Std. Error of the Estimate \\
\hline 1 & $.804^{\mathrm{a}}$ & .646 & .643 & .820 \\
\hline
\end{tabular}

The other output in multiple regression analysis is the model summary with all possible predictor variables included. To five predictor variables and the criterion variable is statistically significant which is different from zero, and there is a relationship between the independent variables and the dependent variable in the population as stated by (Cohen, 2010). construct the model, all predictor variables are included in the first block and the "Method" remains on the default value of 
"Enter". This is because the researcher wants to see the cumulative effect of the predictor variables on the criterion variable.

From the model summary table with the $\mathbf{R}, \mathbf{R}^{2}$, and $a d \mathbf{R}^{2} . \mathbf{R}$ is a measure of the correlation between the observed value and the predicted value of the criterion variable. In our case, this would be the correlation between the effectiveness of instructional leadership function execution and the levels of by the five predictor variables predict. R Square $\left(\mathbf{R}^{2}\right)$ is the square of this measure of correlation and indicates the proportion of the variance in the criterion variable which is accounted by the model. In this case, the effectiveness of instructional leadership function execution were accounted by the predictor variables $(\mathrm{X} 1, \mathrm{X} 2, \mathrm{X} 3, \mathrm{X} 4$ and $\mathrm{X} 5)$.

The output showed that the multiple linear regression model summary. One can find from the same table that the unadjusted multiple $\mathrm{R}^{2}$ for this data is 0.646 , and the adjusted multiple $\mathrm{R}^{2}$ is 0.649 .Here, one can see that there is no significant difference between the unadjusted $\mathrm{R}$ square value and the adjusted $\mathrm{R}$ square values. The five predictor variables together accounted about $0.646(64.6 \%)$ of the variance on the value of the dependent variable (effectiveness of instructional leadership function execution).

The standard error of the estimate is also a measure how much $\mathrm{R}$ is predicted to vary from one sample to the next. In this case, the standard error of the estimate is about 0.820 , which mean the multiple correlation $\mathrm{R}$ between all the predictor variables(X1, X2, X3,X4 and X5) and effectiveness of instructional leadership function execution will vary by $0.82(82 \%)$ if we move from the given sample $(n=351)$ to the next sample $n$.

Table 4.9 Stepwise Multiple Linear Regression to calculate high Predictive Value of the independent variable on Dependent Variable

\begin{tabular}{|c|c|c|c|c|c|c|c|c|}
\hline 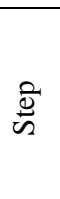 & 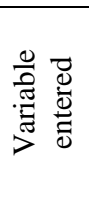 & $\mathrm{R}$ & 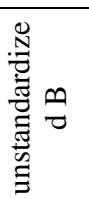 & 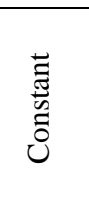 & 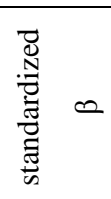 & $\mathrm{R}^{2}$ & $a d \mathbf{R}^{2}$ & 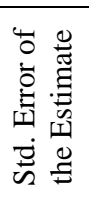 \\
\hline 1 & $\overline{L R}$ & $.648^{\mathrm{a}}$ & -.271 & .877 & -110 & .420 & .398 & .843 \\
\hline \multirow[t]{2}{*}{2} & LR & \multirow[t]{2}{*}{$.751^{\mathrm{b}}$} & \multirow[t]{2}{*}{-.440} & \multirow[t]{2}{*}{1.252} & \multirow[t]{2}{*}{.294} & \multirow{2}{*}{.564} & \multirow{2}{*}{.430} & \multirow{2}{*}{.867} \\
\hline & LC & & & & & & & \\
\hline \multirow{3}{*}{3} & $\begin{array}{ll}\mathrm{LR} \\
\end{array}$ & \multirow{3}{*}{$.791^{\mathrm{c}}$} & \multirow{3}{*}{.572} & \multirow{3}{*}{2.190} & \multirow{3}{*}{.534} & \multirow{3}{*}{.626} & \multirow{3}{*}{.573} & \multirow{3}{*}{.831} \\
\hline & LC & & & & & & & \\
\hline & $\mathrm{LV}$ & & & & & & & \\
\hline \multirow{4}{*}{4} & LR & \multirow{4}{*}{$.799^{\mathrm{d}}$} & \multirow{4}{*}{.119} & \multirow{4}{*}{2.089} & \multirow{4}{*}{.101} & \multirow{4}{*}{.638} & \multirow{4}{*}{.640} & \multirow{4}{*}{.824} \\
\hline & $\mathrm{LC}$ & & & & & & & \\
\hline & LV & & & & & & & \\
\hline & $\begin{array}{l}\text { LST } \\
\end{array}$ & & & & & & & \\
\hline \multirow{5}{*}{5} & LR & \multirow{5}{*}{$.804^{\mathrm{e}}$} & \multirow{5}{*}{.567} & \multirow{5}{*}{1.499} & \multirow{5}{*}{.477} & \multirow{5}{*}{.646} & \multirow{5}{*}{.643} & \multirow{5}{*}{.820} \\
\hline & $\overline{\mathrm{LC}}$ & & & & & & & \\
\hline & $\mathrm{LV}$ & & & & & & & \\
\hline & LST & & & & & & & \\
\hline & LT & & & & & & & \\
\hline
\end{tabular}

From the stepwise analysis of table 4.11 above LR,LC,LV,LST and LT were the variables entered in to the regression equation and they were found the significant contributors of the criterion variable instructional leadership function execution. LR was the first predictor variable entered and it was the most contributors from those other four predictor variables and it was accounted for 0.420 (42\% when $\mathrm{n}=351)$ the variation in instructional leadership function execution. Therefore, to predict instructional leadership using only LR the following formula shown by the line of best fit could be used.

$\mathrm{EILE}=-.271(\mathrm{LR})+.877$
At step two, LC was entered in to the regression equation and it was contributed additional of $14.4 \%$ (when $n=351$ ) of the variation from instructional leadership function execution and together LR and LC contributes $56.4 \%$ of the total prediction. Therefore, to predict instructional leadership execution using this two independent variable LR and LC the following formula used by the line of best fit.

$\mathrm{EILE}=.271(\mathrm{LR})+-.440-(\mathrm{LC})+1.252$

At step three, LV was entered in to the regression equation and it accounted for additional $6.2 \%$ (when $n=351$ ) of the variation in instructional leadership function execution. 
Therefore, to predict instructional leadership execution using LR, LC and LV the following formula was used.

EILE $=-271(L R)+-.440(L C)+.572(L V)+2.190$

At step four, LST was entered in to the regression equation and it accounted for additional $1.2 \%$ (when $n=351$ ) of the variation in instructional leadership execution. Therefore, to predict instructional leadership execution using LR, LC, LV and LST the following formula was also used.

EILE $=-.271($ LR $)+-.440($ LC $)+.572(L V)+.119(L S T)+2.089$

At step five, LT was entered in to the regression equation and it accounted for additional $0.8 \%$ (when $n=351$ ) of the variation in instructional leadership function execution. Therefore, to predict instructional leadership function execution using LR, LC, LV, LST and LT the following formula was also used.

$\mathrm{EILE}=-.271(\mathrm{LR}) \quad+-.440(\mathrm{LC}) \quad+.572(\mathrm{LV})+.119(\mathrm{LST}) \quad+$ $.567(\mathrm{LT})+1.499$

\section{CONCLUSIONS AND RECOMMENDATIONS}

Difference in Instructional Leadership Function Execution among CsTE and Ten Instructional Leadership Function Execution

The researcher was intended to answer the research question about the absence or the existence of statistically significant difference among colleges of teacher education. To answer this research question the one way analysis of variance was conducted. Based on this, the quantitative data analysis results approved that there were statistically significant difference were found between colleges of teacher education $(\mathrm{P}<0.01)$. The same output were produced for the different instructional leadership functions i.e there were statistically significant difference at $\mathrm{P}<0.01$ level among different instructional leadership functions (framing the college goals, communicating college goals, supervision and evaluating instructions, coordinating the curriculum, monitoring students' progress, protecting instructional time, promoting professional development, maintaining high visibility, providing incentives for teachers and providing incentives for learning).

\section{Hindering Factors of Execution of Instructional Leadership Functions}

The other concern of the researcher was to identify the predictive value of the independent variables which was identified by the former scholars. To do this, stepwise multiple regression analysis was conducted. Five independent variable was calculated and their predictive value was also found to be lack of resource (LR), lack of cooperation (LC), lack of vision (LV), lack of skill and training (LST) and lack of time(LT) in which those accounted $64.6 \%$ predictive value on the effectiveness of instructional leadership functions at college of teacher education .

The stepwise multiple linear regressions were employed to calculate the individual and cumulative effect of the selected independent variable on the dependent variable. The researcher has used the selected hampering factors of instructional leadership function execution. The finding of the study showed that the independent variable predicts the dependent variable by $64.6 \%$. From this one can conclude that there were other independent variables which predict the dependent variable which accounts the rest $35.4 \%$. To investigate the opportunities provided for college leaders to execute instructional leadership functions, the four college deans were interviewed and the FGD were conducted with eight vice deans of the college. The response from all four college deans and eight vice deans were almost the same. The response were that both the Regional Education Bureau and Ministry of Education have not given any kinds of support except minimizing the weekly credit hours and they feel that they are the same with all teachers in the concept of instructional leadership functions.

- Plan training about instructional leadership function execution to college deans.

- $\quad$ Solve the problems related with lack of resource (by allocating reasonable budget), lack of vision (to allow them to develop their college vision based on their situation) and it also should cooperate with colleges of teacher education to solve the problems timely.

- The statistically significant mean difference was observed among colleges of teacher education. Based on this finding, the regional education bureau should plan experience sharing between colleges of teacher education.

- The ten instructional leadership functions were found in different level of execution. Using this, the regional education bureau should give due emphasis to those loosely executed instructional leadership functions and block up those gaps.

- All the instructional leadership function, framing goals, communicating goals, incentive for learning and incentives for learning, protecting instructional time, coordinating the curriculum and other functions were not executed properly from the perspective of Hallinger and Murphy(1985). Then, the college deans should work exhaustively to execute that instructional leadership function in collaboration with college teachers and students.

\section{REFERENCES}

[1] Aikman, S., \&Unterhalter, E. (2005).Beyond access: Transforming policy and practice and M. Preedy(eds), Approaches to Post School Management, London: Harper and Row.

[2] American Psychological Association.(2018).Referencing Style Guide.Western Sydney University Library.

[3] Bush,T.(2008).From management to leadership.Educational management, Administration and leadership,36(2):271-288)

[4] Dimmock, C. (2000). redesigning school-based curriculum leadership: A Cross-cultural perspective.Journal of Curriculum and Supervision, 332358.

[5] Foskett, N., \&Lumby, J. (2003).Leading and managing education: International dimension, London: SAGE publications Inc Francisco.

[6] Fullan, M. (2003).The Moral Imperative of School Leadership. Thousand Oaks: Corwin Press.

[7] Ghavifekr and et al(2014).Factors affecting strategic instructional leadership practice of school 
[8] Hallinger, P. \& Murphy, J. (1985). Assessing the instructional management behavior of principals. The Elementary School Journal, 86(2), 217-248.

[9] Hallinger, P. (2003). Leading educational change: Reflections on the practice of instructional and transformational leadership. Cambridge Journal of Education, 229-351.

[10] Hallinger, P. (2009).Leadership For 21st Century Schools: From Instructional Leadership to Leadership for Learning.

[11] Harris and Muijs (2003). Effective Leadership for School Improvement. New York: Rutledge Flamer

[12] Hallinger, P. \& Murphy J. (2012). School leadership that makes a difference: International perspectives. School Effectiveness and School Improvement, 23(4), 359-367.

[13] Hopkins.D. (2005).Instructional Leadership and School Improvement. In Harris et.al eds) Effective Leadership for School Improvement. Rutledge Flamer
[14] Leithwood, K. (1999). Transformational leadership effects: a replication. Schools Effectiveness and School Improvement, 10(4): 451-479.

[15] Maregu B., Firew A., Ashebir B., Gizachew B. \&Alem,A.(2016).Analysis of Educational Management and Leadership Training practice in Ethiopia.Unpublished material.

[16] MoE. (2002) Education Sector Development Program II (ESDP II), Addis Ababa: Ministry of Education.

[17] MoE.(2002). The Education and Training Policy and its Implementation.MoE; Addis Ababa.

[18] Sergiovanni, T.T. (2001). The principal ship: a Reflective practice perspective (4th ed). London: Allyn and Bacon

[19] Syarwan A. \&Maznah H.(2012). Instructional Leadership Practices of the Excellent School Principals in Aceh, Indonesia. 